\title{
Long-term modelling of runoff formation processes at remote mountainous permafrost basin using historical data of short-term special observations (Suntar-Khayata Ridge, Eastern Siberia).
}

\author{
Nataliia Nesterova $^{1}$ and Olga Makarieva ${ }^{1}$ \\ ${ }^{1}$ Melnikov Permafrost Institute of the Siberian Division of the Russian Academy of Sciences
}

August 23, 2020

\begin{abstract}
The study investigates the possibility to parameterize a hydrological model for remote high-altitude permafrost basin based on the data of historical short-term observations conducted in 1957-1959 at the Suntar-Khayata research station (Eastern Siberia) and simulate the changes of runoff observed in recent decades in the region. The Hydrograph model is applied as it has the advantage of using observed physical properties of landscapes as its parameters. The developed parametrization of the goltsy landscape is verified by the results of simulations of variable states of snow and frozen ground. Continuous simulations of streamflow with daily time step are conducted for the period of 1957-2012 at the Suntar River basin (area $7680 \mathrm{~km} 2$, altitude 828-2794 m) with average and median values of Nash-Sutcliff criteria reaching 0.58 and 0.67 respectively. The results of simulations have shown that the largest part of runoff (about 70\%) is formed in the high-altitude area which takes only $44 \%$ of the Suntar River basin area. Simulated series of streamflow reproduce the patterns of recently observed changes, including the increase of low flow, by magnitude of trends and their change period, suggesting that the increase of the increase of liquid precipitation share in autumn months due to air temperature rise can be important factor of streamflow changes in the region. The data presented in the paper are unique for the vast mountainous parts of North-Eastern Eurasia which play important role in general climate circulation. The results indicate that if the assessment of hydrological model parameters is based on observation data instead of calibration, the models can be used in the tasks of studying the response of river basins to climate change with more confidence.
\end{abstract}

Title: Long-term modelling of runoff formation processes at remote mountainous permafrost basin using historical data of short-term special observations (Suntar-Khayata Ridge, Eastern Siberia)

Short running title: Modelling in mountainous permafrost basin

Author names: Nataliia Nesterova ${ }^{1,2^{*}}$, Olga Makarieva ${ }^{1}$

\section{Authors institutional affiliations:}

${ }^{1}$ North-Eastern Permafrost Station, Melnikov Permafrost Institute, Portovaya St., 16, Magadan, Russia 685000

${ }^{2}$ Saint Petersburg State University, Institute of Earth Sciences, 7/9 Universitetskaya nab, St. Petersburg, Russia 199034

*corresponding author:nnesterova1994@gmail.com

\section{Acknowledgements:}

The study was carried out with the support of the RFBR (the research project 19-35-90090). The authors are grateful to Tatiana Vinogradova and David Post for the discussion of the study results and English 
language reviewing.

Keywords: remote high-altitude permafrost basin, hydrological model Hydrograph, short-term observations, parametrization, goltsy, climate change, Suntar River, streamflow, state variables

Long-term modelling of runoff formation processes at remote mountainous permafrost basin using historical data of short-term special observations (Suntar-Khayata Ridge, Eastern Siberia)

Abstract. The study investigates the possibility to parameterize a hydrological model for remote highaltitude permafrost basin based on the data of historical short-term observations conducted in 1957-1959 at the Suntar-Khayata research station (Eastern Siberia) and simulate the changes of runoff observed in recent decades in the region. The Hydrograph model is applied as it has the advantage of using observed physical properties of landscapes as its parameters. The developed parametrization of the goltsy landscape is verified by the results of simulations of variable states of snow and frozen ground. Continuous simulations of streamflow with daily time step are conducted for the period of 1957-2012 at the Suntar River basin (area 7680 $\mathrm{km}^{2}$, altitude 828-2794 m) with average and median values of Nash-Sutcliff criteria reaching 0.58 and 0.67 respectively. The results of simulations have shown that the largest part of runoff (about 70\%) is formed in the high-altitude area which takes only $44 \%$ of the Suntar River basin area. Simulated series of streamflow reproduce the patterns of recently observed changes, including the increase of low flow, by magnitude of trends and their change period, suggesting that the increase of the increase of liquid precipitation share in autumn months due to air temperature rise can be important factor of streamflow changes in the region. The data presented in the paper are unique for the vast mountainous parts of North-Eastern Eurasia which play important role in general climate circulation. The results indicate that if the assessment of hydrological model parameters is based on observation data instead of calibration, the models can be used in the tasks of studying the response of river basins to climate change with more confidence.

Keywords: remote high-altitude permafrost basin, hydrological model Hydrograph, short-term observations, parametrization, goltsy, climate change, Suntar River, streamflow, state variables

\section{Introduction}

The Arctic regions are experiencing unprecedented changes of climate (IPCC, 2014). Mountainous areas of the Arctic are the remotest, less studied but provide the largest share of Arctic runoff (Hinzman et al., 2005; Viviroli et al., 2011). Recent studies have shown that due to climate warming Arctic runoff is changing too (Makarieva et al. 2019a; Rawlins et al., 2010; Stuefer et al., 2017; Tananaev et al., 2016) but the mechanisms behind observed changes are not fully understood.

The lack of data can partly be compensated by hydrological modelling. Models are also used for projections of future states of hydrological system in the Arctic (Krogh \& Pomeroy, 2018; Pohl et al., 2006; Rasouli et al., 2014).

The problematic issue of future projections is that large-scale, relatively simple, conceptual hydrological models are being calibrated against streamflow series in gauging stations of large rivers (Hudson \& Thompson, 2019; Nijssen et al., 2001), while more process-based ones, require detailed observational information for their parametrization and are usually applied for well-studied research basins (Changing Cold Regions Network project, Improving Processes \& Parameterization for Prediction in Cold Regions Hydrology project; Marsh et al., 2020; Zhang et al.. 2008). It is not very often that hydrological models are tested if they are really able to reproduce currently observed changes before issuing the future projections. These problems undermine the ability of hydrological community to deal with Arctic warming challenge.

The study advocates the approach to hydrological modeling presented in earlier papers (Semenova \& Beven, 2015; Semenova et al., 2013; Vinogradov et al., 2011) which suggest a priori or based on expert judgement estimation of model parameters and extensive verification of models and the sets of their parameters as the tool of comprehension of hydrological process in ungauged basins.

The tasks of the study are: 
* Compile the database of available historical observations (1957-1959) for remote mountainous river basin located in the zone of continuous permafrost with long-term streamflow series and pronounced changes of hydrological regime in recent decades.

* Describe runoff generation processes; parameterize the hydrological model using compiled data and the results of previous regionalization of the model parameters.

* Verify the model based on available observations of variable states of snow and frozen ground.

* Verify the model by streamflow for the continuous period of observations (1956-2012).

* Assess the ability of the model to reproduce the recent changes of streamflow.

* Investigate the factors of streamflow changes using the hydrological model.

The novelty of the study is the approach that allow for continuous long-term simulations of streamflow and active layer dynamic in remote basin with complicated mountainous permafrost environment based on process understanding and scarce data of short-term observations conducted more than 60 years ago.

\section{Research area and study basin}

The Suntar River basin at the Sakharyniya river mouth (basin area $7680 \mathrm{~km}^{2}$ ) was selected as the object of the study (Fig. 1). This river belongs to the Indigirka river basin and drains from the Suntar-Khayata Ridge which is a continuation of the Verkhoyansk mountain system (Eastern Siberia). In the central parts of the south it is adjacent to the Ugamskiy Ridge. Together, they form triple headwaters between the Indigirka basin in the northeast, the Aldan basin in the west, and the rivers of the Okhotsk sea basin in the south. The slopes of the Suntar-Khayata Ridge are very divers: high peaks (the Mus-Haya mountain, 2959 m a.s.l.) are combined with deep river valleys.

The climate of the region is extremely continental with altitudinal zonation and air temperature inversions in the cold season. Average annual temperature is -13.8 and $-14 .{ }^{\circ} \mathrm{C}$ (in July +6.4 and $+17.5{ }^{\circ} \mathrm{C}$, in January -28.0 and $-39.6{ }^{\circ} \mathrm{C}$ ) at the stations of Suntar-Hayata (2068 m a.s.l.) for the period 1957-1964 and Agayakan (776 m a.s.l.) for the period 1957-2012 correspondingly. Annual average precipitation at the Vostochnaya (1966-2012) is $280 \mathrm{~mm}$ and at the Suntar-Hayata (1957-1964) is about $690 \mathrm{~mm}$. Most precipitation occurs in summer (Vostochnaya, 1966-2012).

The studied territory is situated in the region of continuous permafrost, its thickness within the mountain ranges is about $400-600 \mathrm{~m}$, and under river valleys it is 200-300 $\mathrm{m}$ (Geocryology of the USSR, 1989). However, permafrost can be interrupted in fractured zones by taliks associated with intrapermafrost and suprapermafrost water flow (Grave et al., 1964).

The study area belongs to the northern taiga climate zone which is affected by altitude and aspects of mountain slopes. According to (Landscape map of the USSR, 1985) the following landscape units can be found within the study region. They are 1) lowland plains, sometimes swampy, with larch woodlands or larch forests in combination with hummock and moss tundra; 2) the plateaus with gentle slopes with stony-lichen and shrub tundra and larch woodlands; 3) ridge mountains with stony and stony-lichen tundra and areas of larch woodlands in the valleys.

The tundra areas are located from the absolute altitudes of 1500-1550 m (from $1400 \mathrm{~m}$ under the glaciers). The main feature of the overlying high-altitude zone $(1600-2100 \mathrm{~m})$ is the predominance of lichens and almost complete absence of shrubs and flowering plants.

The average altitude of the Suntar river basin is $1410 \mathrm{~m}$ a.s.l. from $2794 \mathrm{~m}$ a.s.l. to $828 \mathrm{~m}$ a.s.l. Therefore, the basin covers the landscapes from upper reaches of the mountains to the lowland plains in the river valley.

The Suntar river regime is characterized by high spring freshet and rain summer-autumn floods. In winter, the Suntar River freezes completely. Maximum streamflow is observed in the summer months. Snow cover is formed in September. Usually a spring freshet begins in the third week of May. Average annual flow for 
the Suntar river is about $180 \mathrm{~mm}$, with a maximum recorded daily discharge of $1900 \mathrm{~m}^{3} / \mathrm{s}$ (1957-1964). Water levels at the gauge range from $198 \mathrm{~cm}$ (1964) to $781 \mathrm{~cm}$ (1980) (Fig. 2) with the variation of river depth up to $6 \mathrm{~m}$. Daily streamflow data (1956-2015) for hydrological gauge originate from the publications of the Hydrological Yearbooks (Hydrological Yearbooks, 1936-1980; State Water Cadastre, 1981-2007) and are available for the period 2008-2015 on the website of the Automated information data system for state monitoring of water bodies (AIS SMWB) (URL: https://gmvo.skniivh.ru, reference date: 01.03.2018).

About two dozen small glaciers with areas from 0.05 to $2.7 \mathrm{~km}^{2}$ and total area of $14.7 \mathrm{~km}^{2}$ are located within the upstreams of the Suntar River (GLIMS and NSIDC, 2005, updated 2017) (Fig.1). This accounts for 0.2\% of the Suntar River basin area. There are no direct estimates of glacier streamflow for the Suntar River basin, but according to Grave et al. (1964), specific rate of flow of all the glaciers of the Suntar-Khayata Ridge in 1957, 1958 and 1959 was about 17, 13 and $22 \mathrm{ls}^{-1} \mathrm{~km}^{2}$, respectively. The glaciers' contribution to river streamflow in the catchments with higher glacier areas can be significant. Grave et al. (1964) assessed the values for the neighboring basin of the Agayakan river, where glaciers cover over $2.2 \%$ of the catchment. In 1957, which was average by hydrological conditions, the glaciers contribution exceeded $3.8 \%$ of the overall annual flow and reached $6.1 \%$ of flow in July and August.

In the last decades, a steady decreasing trend of the Suntar-Khayata Ridge glacierization has been observed (Lytkin, 2016) which sums up to a reduction in area of about $20 \%$ over the period 1945 to 2003 (Ananicheva, 2005). In this study we assume that the contribution of the glaciers in the Suntar river flow is likely to be smaller than the precipitation assessment error and cannot really be accounted for explicitly due to a lack of information.

There are numerous aufeis fields that are formed at mountain ranges, in submountain and intermountain depressions in the study region. In the Suntar river basin, the aufeis cover up to $0.76 \%$ of basin area (Makarieva et al., 2018c; 2019b). In the last 70 years the amount of aufeis fields at the Suntar river basin has increased from 45 to 53 , and their total area has decreased from $75 \mathrm{~km}^{2}$ to $60 \mathrm{~km}^{2}$ (Fig.1) (Makarieva et al., 2018c). The aufeis flow contribution is most significant in May-June (Sokolov, 1975). Following the approach by Sokolov (1975) we estimated that the share of aufeis runoff for the Suntar river basin may reach $9.2 \%(17.4 \mathrm{~mm})$.

Perennial snow fields and rock glaciers are widespread within the Suntar-Khayata Ridge (USSR surface waters resources, 1966). They, along with the ice of the active layer and summer atmosphere precipitation, may represent a significant source of streamflow, however in this respect they have barely been studied (Lytkin, 2016; Zhizhin et al., 2012).

\section{Special observations}

The high-altitude Suntar-Khayata Station was operating in the Suntar River basin in 1957-1959 under the program of the International Geophysical Year (Dodds et al., 2010). Glaciological, geomorphological, geocryological and hydrological observations were carried out (Grave et al., 1964). The Station was located at an altitude of $2067 \mathrm{~m}$ in a rocky talus (goltsy) landscape and the observations are unique for the highmountain areas of Eastern Siberia and the North-East of Russia.

We systematized the observations from the Station, which included meteorological data, snow measurements, evaporation data, the descriptions of soils and landscapes, the data on typical active layer depth, ground temperature at various depths, etc. (Grave, 1959; Grave et al., 1964; Grave \& Koreisha, 1957, 1960; Koreisha, 1963).

According to the results of the Station studies and descriptions, the high-altitude landscapes zoning of the Suntar River basin was elaborated:

- Goltsy (or rocky-talus, completely bare landscape) is located in the altitude range 1900 to $2700 \mathrm{~m}$ a.s.l. (average height is $2040 \mathrm{~m}$ ), its share accounts for $7 \%$ of the Suntar river basin. Ground profile consists of argillite broken stone with admixed loam materials, cemented together with ice and the layers of clean ice up to $2 \mathrm{~m}$ depth. Vegetation is absent. Despite significant amount of precipitation and its 
irregular distribution, the upper layer of diluvia is characterized by low moisture content and its barely visible variations during the warm season. It is explained by the high permeability of broken rocks. Unevaporated water easily infiltrates deep down and flows along the frozen bedrock. The unsuccessful experience of experimental runoff site construction had shown that the bedrock has deep splits and hollows, and even though their temperature is below zero, they are not fully filled with ice (Grave, 1959).

- Mountain tundra is located within the altitudes of 1450-1900 m a.s.l. (1630 m on average) and takes $37 \%$ of the Suntar River basin. It has tight and depressed layer of grass and moss with bushes under which there is rock formation with some ice with admixtures.

- Sparse larch forest (1100-1450 m a.s.l., $1310 \mathrm{~m}$ on average) consists of sparse growth of larch forest at north slopes and larch forest at south slopes, and covers $42 \%$ of the basin.

- Swampy sparse larch forest is spread within the river valleys and floodplains (828-1100 m a.s.l., 1060 $\mathrm{m}$ on average) and covers $14 \%$ of the basin.

The active layer depth within the study territory is very variable. Table 1 shows some data on maximum active layer depth, obtained in 1958. In the high mountainous area of the altitude $1700 \mathrm{~m}$ and above, the depth of thawing of rocky talus sediments ranges from zero under glaciers and perennial snowfields to $70-90 \mathrm{~cm}$ at the foot of the slopes at the alluvial cone, folded by gravelly loam. Observed values at the Suntar-Khayata Station reached $75 \mathrm{~cm}$ in 1958 and $90 \mathrm{~cm}$ in 1959 (Grave et al., 1964). On steep slopes with southern exposure, the depth of penetration of positive temperature into the ground is expected to be greater. In similar landscapes with the same conditions, large-scale crushed stone thaws up to $55-60 \mathrm{~cm}$ during the season, and crushed loam thaws up to $80-85 \mathrm{~cm}$. Observations show that large-scale sediments at the time when the snow comes down are firmly cemented by ice, which fills all the pores between the material. The data indicates that the variation of active layer depth in the high-altitude area is significantly variable over individual years. The depth of the seasonal thaw layer is more stable in the mid-mountain region. The maximum depth of thawing is observed in coarse-grained rocks this region. In sand-gravel-pebble ground at an altitude of about $1400 \mathrm{~m}$, the depth of seasonal thawing reaches 120-150 cm and in loam soils ranges from 25 to $30 \mathrm{~cm}$, depending on the moisture content (Grave et al., 1964).

\section{Hydrograph model}

The Hydrograph model is a distributed process-based hydrological modelling system (Vinogradov et al., 2011). It describes all components of the land hydrological cycle, including precipitation and its interception; snow accumulation and melting; evaporation from snow, soil, and vegetation cover; surface flow and infiltration; soil water dynamics and flow; heat dynamics and phase change in soil layers; underground flow formation, slope and channel flow transformation. The model requires the following atmospheric variables as its input: air temperature and humidity, the amount of precipitation. The output are flow hydrographs, water balance and state variables of basin elements. The model can be run at time steps from minutes and hours to daily.

The concept of runoff elements used in the Hydrograph model for spatial discretization of basins is a key concept. The catchment area consists of runoff elements of different levels - surface, soil and underground. The concept proposes the system of runoff elements characteristics, such as outflow time which include the time and intensity of outflow from elements, depending on the water storage (Vinogradov et al., 2011).

Within the discretization procedure, the basin territory is divided into several conditionally homogeneous parts called runoff formation complexes (RFC). It is assumed that the characteristics of soil, vegetation, topography, and other components of the landscape are constant within each RFC, while the runoff formation process is uniform. The main parameters of the model are the physical properties of the landscapes that may be observed in nature and are classified according to the types of soil (specific weight, specific heat capacity of soil particles, specific heat conductivity of dry soil particles, porosity, maximum water holding capacity, wilting point, ice impedance factor, infiltration coefficient, hydraulic parameter of subsurface system of runoff elements), vegetation (seasonal shadiness by vegetation cover, landscape albedo, interception storage capacity, coefficient of evaporation from the interception storage during the maximum development 
of vegetation cover, parameter of heat supply from atmosphere to soil surface, phenological dates) and other characteristics (Vinogradov et al., 2011; Semenov et al., 2013).

The method for simulating thermal dynamics in the upper layer of ground is incorporated in the Hydrograph model. It is based on several techniques that simplify the differential equation of thermal conductivity in the soil profile and allows bringing the system of differential equations to a system of linear algebraic equations without losing the quality of the simulation results (Lebedeva et al., 2015; Semenova et al., 2015).

The Hydrograph model has been successfully applied to simulate the river runoff formation in cold regions with a lack of ground-based observation data (Semenova et al., 2013; Semenova et al., 2015; Vinogradov et al., 2011). Here we present the results of parameterization and verification of the Hydrograph model for mountainous landscapes of the North-East of Russia based on the data of short-term special observations. For modeling, the Suntar River basin is presented as a hexagonal grid, with 32 representative points (RP) (Fig. 1). Each RP has its own set of point characteristics, which include the coordinates, latitude, elevation, slope aspect, slope inclination and lag time.

\section{Model parameterization and input data}

\subsection{Parameterization}

The parametrization of the Hydrograph model was performed based on joint analysis of available field descriptions of ground hydrothermal regime and corresponding patterns of runoff formation in typical landscapes (Vinogradov et al., 2011). According to altitudinal zonation, the catchment of the Suntar river is divided into 4 RFCs which are presented above: goltsy (RFC \#1), mountain tundra (RFC \#2), sparse larch forest (RFC \#3), swampy sparse larch forest at waterlogged soils (RFC \#4) (Fig. 1). For each RFC, a schematization of the vertical profile is developed that considers vegetation, soil composition, snow accumulation features and runoff formation processes. In the Hydrograph model the soil column is divided into computational soil layers (CSL), which may have different depths but it is usually taken to be equal to $10 \mathrm{~cm}$, and the total depth of the calculated soil profile should exceed the maximum active layer depth, if the model is applied to the permafrost zone. In this study the calculation depth of the ground column was taken as 2 meters (20 CSL by $10 \mathrm{~cm}$ ). This value is assigned from the assumption of maximum possible active layer depth (150 cm) (Grave, 1964).

\section{RFC \#1}

The parametrization of goltsy landscape was developed with the use of observational data from the SuntarKhayata Station (Grave, 1959; Grave \& Koreisha, 1957, 1960; Koreisha, 1963).

The set of the model parameters representing physical properties of the soil (ground) column was elaborated based on the detailed description of goltsy landscape, its ground profiles (Grave \& Koreisha, 1957) and physical properties of ground column at different depths, such as density, porosity, water capacity, heat conductivity (Table 2) (Grave, 1959; Grave \& Koreisha, 1960; Grave et al., 1964; Koreisha, 1963).

Assigned values of specific density and porosity for all 20 CSL are $2700 \mathrm{~kg} / \mathrm{m}^{3}$ and $42 \%$. Maximum water holding capacity is 0.12; maximum ice holding capacity is $0.22-0.32$ according to Grave (1959) and is taken as an average value of 0.26 . Specific heat capacity of ground particles in dry condition accounts for 840 $\mathrm{J} / \mathrm{kg}{ }^{\circ} \mathrm{C}$, and specific heat conductivity $-1.5 \mathrm{~W} / \mathrm{m}{ }^{\circ} \mathrm{C}$. The infiltration coefficient (assigned as 10, 5, 1 and $0.1 \mathrm{~mm} / \mathrm{min}$ for the ground layers $10,20,30 \mathrm{~cm}$ and below $30 \mathrm{~cm}$, respectively) was not determined at the Suntar-Khayata Station and is adopted from (Semenova et al., 2013) for similar landscape of the Kolyma water balance station.

The hydraulic parameters of the runoff elements (1) in ground profile (Semenova et al., 2013; Vinogradov et al., 2011) were determined by manual calibration using the observed hydrographs and based on the general ideas about the runoff formation processes. For example, runoff generation in the upper horizon of ground profile is much faster than in the mineral layer. The value of this parameter is estimated as 10 at the upper layer and 0.005 at the bottom layer. 
The boundary conditions of the ground temperature at a constant depth were taken from the average monthly soil temperature data at the $4 \mathrm{~m}$ depth at the Suntar-Khayata Station in 1958. The minimum value of the ground temperature reaches $-11.7^{\circ} \mathrm{C}$ in May, the maximum is $-6.7^{\circ} \mathrm{C}$ in October.

The parameter of heat supply from the atmosphere to soil surface may be treated as the heat transfer coefficient between atmosphere and soil surface under conditions of instantaneous energy withdrawal from the surface of contact. Depending on the vegetation density above the soil surface, the value of the parameter changes with increasing vegetation height/density from 1.0 (RFC \#1) to 3.0 (RFC\#3-4) (Semenova et al., 2014).

RFC \#2-4

Assuming that runoff formation processes in mountainous regions of the Kolyma river upstreams and in the Suntar river basin are similar, the parameters for RFC \#2-4 were adopted from (Lebedeva et al., 2014; Makarieva et al., 2020; Semenova et al., 2013), who assessed them based on detailed data from the Kolyma water-balance station (Makarieva et al., 2017, 2018a).

\subsection{Meteorological information}

Daily air temperature and humidity, precipitation totals from meteorological stations of hydrometeorological network within or nearby the basin were used as meteorological input for hydrological modelling. Four of them, Suntar-Khayata, Nizhnyaya Baza, Vostochnaya and Agayakan, were used for the period 1957-1964 and two, Agayakan and Vostochnaya, for the period 1966-2012 (Table 3, Fig. 1). Input data from meteorological stations are interpolated to each RP. The interpolation is based on the triangulation method, when ideally each RP is inside a triangle, in the corners of which there are weather stations. Linear interpolation is conducted between the stations, if only two are available.

\subsubsection{Distribution of air temperature and humidity with elevation}

The study area is characterized by temperature inversions. Annual average monthly temperature and air saturation deficit lapse rates were estimated using the data from the Suntar-Khayata and Agayakan meteorological stations (the range of elevation is $1292 \mathrm{~m}$ ), they change from $+1.1{ }^{\circ} \mathrm{C}$ and $+0.01 \mathrm{mbar}$ per $100 \mathrm{~m}$ elevation increase in January to $-1.3{ }^{\circ} \mathrm{C}$ and -0.35 mbar per $100 \mathrm{~m}$ in June. The estimated values were used to correct interpolated temperature and saturation deficit from meteorological stations to RP depending on the difference of elevation.

\subsubsection{Distribution of precipitation with elevation}

The data of four meteorological stations (Suntar-Khayata, Nizhnyaya Baza, Vostochnaya and Agayakan) from Reference book (1968) and the information of snow surveys at high mountain elevation (Grave, 1960) were used to analyze the distribution of precipitation at different altitudes for warm (May - August) and cold (September - April) periods of the year.

Annual precipitation at the Suntar-Khayata Station exceeds the precipitation amount observed at foothills by more than twofold. Precipitation gradient at the altitude range 777 to $1350 \mathrm{~m}$ a.s.l. is $7 \mathrm{~mm}$ (5-7\%) per $100 \mathrm{~m}$, and at the altitude range 1350 to $2068 \mathrm{~m}$ a.s.l. it exceeds $35 \mathrm{~mm}$ (15-16\%). Snow survey data for 1957-1959 (Grave, 1960) had demonstrated that altitudinal gradients of precipitation increase are steady and equal on average to $35(5-8 \%)$ and $30(4-5 \%) \mathrm{mm}$ per $100 \mathrm{~m}$ for the altitude ranges of 2068-2257 and 2257-2477 $\mathrm{m}$ a.s.l. correspondingly.

Solid precipitation share at $777 \mathrm{~m}$ a.s.l. is approximately $25 \%$ of the annual total, and at $2068 \mathrm{~m}$ a.s.l. it increases to 60\%. Mean annual precipitation from 1957 to 1964 at the Suntar-Khayata Station according to the rain gauge data is $555 \mathrm{~mm}$.

Correct estimation of precipitation is difficult in mountainous areas, significant biases occur especially for winter precipitation under effect of the wind on snowfall (Groisman et al., 2014). There are several methods for precipitation corrections. They are mainly based on the coefficient on wind speed and wind protection, 
air temperature and precipitation type (WMO Report no. 67, 1998; Yang \& Goodison, 1995). In Reference Book (1968) some adjustments are recommended for wind underestimation and wetting loss, which can reach up to 1.7 times (1.6 on average in cold season) for solid precipitation, and 1.3 times (1.16 times on average in warm season) for liquid precipitation, which leads to the annual precipitation amounts of $688 \mathrm{~mm}$ at 2068 m a.s.l. (Reference Book, 1968), and $800 \mathrm{~mm}$ at the mountains peaks (Vasiliev \& Torgovkin, 2002).

Corrected values of precipitation at meteorological stations were used to develop the dependencies between both liquid and solid precipitation amount and terrain elevation in the basin. Precipitation amount for each $\mathrm{RP}$ is assessed according to those dependencies based on its elevation and interpolated daily solid and liquid sums of precipitation are normalized.

\section{Hydrograph model verification based on special observation}

We used available observational data from the Suntar-Khayata Station to verify the model parameterization for the goltsy landscape.

\subsection{Ground temperature}

Geothermal measurements were carried out at the Suntar-Khayata Station site in three boreholes at depths down to 10-20 $\mathrm{m}$ in 1958. Temperature measurements were made 4 times a day at depth horizons to a depth of $1 \mathrm{~m}$, once a day to a depth of $5 \mathrm{~m}$ and once every five days on deeper horizons. Average monthly ground temperatures at numerous horizons were published in Grave (1959). We used these data to verify ground temperature modeling which was conducted on a daily time step at different depths using thermal-physical soil properties. Mean absolute deviations between simulated and observed monthly temperatures accounted for $1.1{ }^{\circ} \mathrm{C}, 0.7{ }^{\circ} \mathrm{C}, 0.2{ }^{\circ} \mathrm{C}$ and $0.3^{\circ} \mathrm{C}$, and their maximum values $-+3.6{ }^{\circ} \mathrm{C}$ (December), $+4.0{ }^{\circ} \mathrm{C}$ (November), $+2.4{ }^{\circ} \mathrm{C}$ (June) and $-1.7{ }^{\circ} \mathrm{C}$ (January) at $5,50,100$ and $200 \mathrm{~cm}$ depths correspondingly in 1958 (Table 4). Overall, modelled soil temperature values at different depths provide a good fit to the observed values (Fig. $3)$.

\subsection{Active layer depths}

Ground thaw starts in mid-June and continues to mid-September. According to Grave (1964) maximum active layer thickness (ALT) reaches $75 \mathrm{~cm}$ at the goltsy landscape and 30-45 cm at the swampy landscape (Table 1).

For simulating ALT at the goltsy landscape we varied two types of initial conditions: 1) with lenses of ground ice in upper part of soil profile and 2) without ground ice. In the first case (with ground ice) the average simulated ALT (1957-1964) is $32 \mathrm{~cm}$ with the range from $20 \mathrm{~cm}$ (1958) to $42 \mathrm{~cm}$ (1960) at RFC \#1 (Fig. 4). The same values are $33 \mathrm{~cm}$ for the period 1966-2012 with maximum $70 \mathrm{~cm}$ in 1968 and minimum $2 \mathrm{~cm}$ in 1979. In the second case (without ground ice) simulated ALT varies in the range of $50-80 \mathrm{~cm}$ for the period 1957-2012.

The average simulated depth of the active layer (1966-2012) at the RFC \#2 is $180 \mathrm{~cm}$, at the RFC \#3 is $122 \mathrm{~cm}$, at the RFC \#4 is $67 \mathrm{~cm}$. In general simulated ALT exceed observed values in those landscapes for which the model parameters were adopted from the study at the Kolyma water-balance station (Makarieva et al., 2018a).

For example, mean ALT values in tundra and rocky talus landscapes are about $1.5 \mathrm{~m}$ there, reaching 2.5 $\mathrm{m}$ at steep southern slopes due to higher air temperatures and longer freeze-free period (about 130 days compared to 55 days at the Suntar-Khayata Station).

It is important to mention that there are no statistically significant increasing trends of simulated ALT values in long-term period.

\subsection{Snow cover}

Snow measurements were conducted at the meteorological site of the Suntar-Khayata Station at the altitude of $2070 \mathrm{~m}$. The triangle plot with the sides of $12 \mathrm{~m}$ was instrumented with three rails installed in the corners 
where snow height and volume weight were measured each 10 days (Koreisha, 1963). The snow data are available only for two years (1958-1959).

At the altitude of the Suntar-Khayata Station, snow cover is formed in early September and melts only in the second part of June - early July. The snow-free period lasts about 2 months, (on average 56 days in 1957-1959).

Snow water equivalent (SWE) varies greatly from year to year. Maximum observed SWE reached $348 \mathrm{~mm}$ in 1958 and only $153 \mathrm{~mm}$ in 1959. Maximum simulated SWE amounted to $363 \mathrm{~mm}$ in 1958 and $171 \mathrm{~mm}$ in 1959. Mean simulated SWE by the end of winter for the period of 1957-1964 was $251 \mathrm{~mm}$.

Mean deviation value between simulated and observed daily SWE is $18.4 \mathrm{~mm}$. The maximum deviation value reached $43 \mathrm{~mm}$ on November 20th, 1958. The absolute error of simulated maximum SWE is 5-12\% during 1958-1959. Mean simulated SWE by the end of winter for the period of 1966-2012 was $213 \mathrm{~mm}$ and range from $114 \mathrm{~mm}$ (1983) to 379 (1967). The height of snow changed from $44 \mathrm{~cm}$ to $99 \mathrm{~cm}$ and the mean value was $70 \mathrm{~cm}$.

The comparison of simulated and observed values of SWE during winter seasons 1958-1959 is presented in Fig. 4 and shows general model adequacy. It is noteworthy that modelling results show that the snow cover formed within 5 days from 5 to 10 August 1957 and then melted (Fig. 4). The modelling results of the same variable state at the Canadian Rocky Mountains watersheds shows that overestimation or underestimation of the peak SWE ranged from 2.4 to $16 \%$ for the upper watershed landscapes (Fang et al., 2013).

Also snow surveys were conducted at the territory adjacent to the Suntar-Khayata Station along the 3-km long route with elevation range over $400 \mathrm{~m}$ (2068-2477) in 1957-1959. Spatial variation coefficient of snow redistribution was calculated based on the data as 0.60. A normal distribution (Vinogradov et al. 2011) was used to statistically account for snow redistribution in the goltsy landscape based on this estimation. In general, this value is consistent with the data on snow variation for mountainous landscapes in the Yukon River Basin (SWE variation is 0.69 by McCartney et al. (2006), 0.48 by Pomeroy et al. (2004) and 0.69-0.84 in the upstreams of Kolyma River based on the data by Makarieva et al. (2018a).

\subsection{Evapotranspiration}

Assessment of evapotranspiration (ET) is the very problematic for this region due to the lack of the data. Annual values of ET for goltsy landscape at the Morozova Creek watershed (altitude range 1100-1700 m a.s.l.) was estimated based on the water balance data of the Kolyma water balance station (KWBS) in the range from $70 \mathrm{~mm}$ (Lebedeva et al., 2017) to $92 \mathrm{~mm}$ (Makarieva et al., 2018a). In the Upper Wolf-Creek catchment (part of the southern headwaters of the Yukon River, Canada) with tundra and shrub-tundra environment and elevation reaching $2250 \mathrm{~m}$ annual value of ET reached $135 \mathrm{~mm}$ (Janowicz et al., 2004). The assessment for the Upper Kuparuk (elevation range of 698-1464 m) and Imnavait River basins (elevation range from 844 to $960 \mathrm{~m}$ ) (Alaska) from tundra landscape was about 140 and $178 \mathrm{~mm}$ respectively (Schramm et al., 2007). In the the Tana River Basin (Finnish Tenojoki), with the mean air temperature -6@C at the highest mountain tops $(1010 \mathrm{~m})$, annual values of snow sublimation and evapotranspiration was estimated as 90 and $58 \mathrm{~mm}$ respectively (Dankers \& Chrisrensen, 2005). The assessment of total annual evaporation at the Axel Heiberg Island at the Canadian Arctic Archipelago was about 140 mm (Ohmura, 1982).

The observations of ET from the ground surface at the Suntar-Khayata station were carried in 1958 (Grave, 1959). Two land evaporimeters GGI-500 were used (Makarieva et al., 2018a). The evaporimeters were installed in early June 1958, when the snowpack was continuous, had not started melting yet, and ground temperature was below zero. Evaporation tanks were filled with soil from the Suntar-Khayata Station site and left under snow until it completely melted at the site on July 20-27, 1958. The observations continued throughout August 1958. Evaporation tanks were weighted every 5 days, precipitation was registered daily in direct proximity to them (Grave, 1959). In August 1958 observed values of precipitation accounted for 77 $\mathrm{mm}$, infiltration rate $-36 \mathrm{~mm}, \mathrm{ET}-44 \mathrm{~mm}$ (about $1.4 \mathrm{~mm}$ per day).

Compared to the ET assessments for the KWBS watersheds where free-snow season lasts twice longer and 
mean summer values of air moisture deficit are 1.5 times higher than at the Suntar-Khayata Station, we question this single result of observations and suggest that the value of $44 \mathrm{~mm}$ is significantly overestimated.

In the Hydrograph model the amount of ET is calculated taking into account the potential evaporation, initial amount of moisture in soil layers, maximum water holding capacity of the soil, the fraction of contribution of a given soil layer to total evaporation, the value of which depends on soil and vegetation type (Semenova et al., 2013). To estimate ET we adopted the evaporation coefficient parameter from the modelling studies conducted for the Kolyma water-balance station (Semenova et al., 2013; Makarieva et al., 2020). Its value for goltsy landscape is $9^{*} 10^{-10} \mathrm{~m}\left(\mathrm{hPa}^{*} \mathrm{~s}\right)^{-1}$. Simulated ET values were $19 \mathrm{~mm}$ in August, 1958 and $43 \mathrm{~mm}$ on average during snow free season for the whole period of simulations. Adding $11 \mathrm{~mm}$ of snow evaporation it gives us about $54 \mathrm{~mm}$ of annual total evaporation at the goltsy landscape.

\section{Results of streamflow modeling}

Continuous runoff modeling with daily temporal resolution was carried out for the Suntar river basin for the period 1957-1964, using input meteorological data from four meteorological stations (Suntar-Khayata, Nizhnyaya Baza, Vostochnaya and Agayakan); and for the period 1966-2012 using the data from two stations (Vostochnaya and Agayakan). Water balance components distribution for these periods are presented in Table 5, and the comparison of observed and calculated streamflow hydrographs - in Fig. 5, Fig. 6.

Calculated mean annual precipitation for the Suntar river basin is $344 \mathrm{~mm}$ for the 1957-1964 period. Estimated streamflow is $199 \mathrm{~mm}$, which is $10 \%$ higher than the observed value $(180 \mathrm{~mm})$. Estimated ET from the whole basin equaled $143 \mathrm{~mm}$.

Maximum precipitation and streamflow annual values for the entire simulation period reached 486 and 348 $\mathrm{mm}$ in 1959, while minimum values were $259 \mathrm{~mm}$ in 1958 and $136 \mathrm{~mm}$ in 1963 for the Suntar River basin. The coefficient of variation of annual streamflow is 0.30 .

Here we compare the water balance distribution with other research basin in the region, the KWBS station, the Kontakovy creek watershed (area $21.3 \mathrm{~km}^{2}$, average altitude $1070 \mathrm{~m}$ ). The value of ET for the KWBS is assessed within the range from 114 to $137 \mathrm{~mm}$ (Lebedeva et al., 2017; Zhuravin, 2004). Mean annual precipitation and streamflow reached 420 and $280 \mathrm{~mm}$ for the period 1948-1997.

The average and median Nash-Sutcliffe efficiency (NS) for the Suntar River amounted to 0.75 in 19571964. The same value for the period of 1966-2012 is lower (average 0.58, median 0.67 with maximum and minimum values of 0.88 and -0.90 , respectively). We attribute this decrease of efficiency to the lack of meteorological data in the second period. Overall, despite some overestimation of streamflow, the calculated streamflow hydrographs match the observed ones quite satisfactorily, both in phases and absolute discharge values. Overestimation of simulated streamflow during spring freshet may be associated with the spread of underchannel taliks. In spring dry alluvial deposits in the river channels are filled with snowmelt water and delay the start of freshet and decrease its magnitude (Grave et al., 1964). Such phenomena are also described by Mikhaylov (2013).

We also compared simulated and observed maximum discharges. The maximum simulated and observed discharges were 1200 and 1659 respectively during 1957-1964 and 1905 and 1910 during 1966-2012 for the Suntar River basin (Table).

Based on the simulation results, the contribution of each runoff formation complex (RFC) into total streamflow of the Suntar River was evaluated (Table 6, Fig. 7). Goltsy complex that covers only $7 \%$ of the basin provides $20 \%$ of the total streamflow, and the runoff coefficient reaches 0.91 . Tundra is the largest contributor to the runoff formation at the Suntar river catchment - $49 \%$ of the total runoff, with a runoff coefficient of 0.74 . The total streamflow from the taiga and sparse forest landscapes, which take $56 \%$ of the territory, is about $31 \%$. The contribution of the goltsy landscape increases in dry years and may reach up to $28 \%$ (for example, in 1963 the total annual streamflow was only $130 \mathrm{~mm}$, while the streamflow from the goltsy complex was simulated as $513 \mathrm{~mm}$ ). 


\section{Simulated streamflow trends}

Studying the mechanisms of runoff regime transformation changes in the Arctic basins in current and future climate conditions is important research task. In general, river streamflow in Northern Eurasia and North America is increasing (Shiklomanov \& Lammers, 2013). Most of the rivers exhibit the increase of winter base flow (Makarieva et al. 2019a; Spence et al., 2011; Tananaev et al., 2016) and there are different hypothesis about the factors of such changes. The analysis of monthly streamflow data in the basins of the Yana and Indigirka Rivers $(1936-2015)$ has shown the presence of statistically significant $(\mathrm{p}<0.05)$ positive trends in May and autumn period (Makarieva et al., 2019a). The values of trends for the Suntar River are the following: $6.8 \mathrm{~mm}$ or $103 \%$ in May, $9.9 \mathrm{~mm}$ or $49 \%$ in September, $3.3 \mathrm{~mm}$ or $70 \%$ in October and 0.43 $\mathrm{mm}$ or $52 \%$ in November (Makarieva et al., 2019a). There is a decrease in precipitation in winter (minus 8 to $13 \mathrm{~mm}$ ) and the absence of significant changes in other seasons. The rise of annual air temperature by $+2,0^{\circ} \mathrm{C}$ led to an increase in the amount of liquid precipitation and streamflow in September by about 12 $\mathrm{mm}$. The revealed dependences of monthly streamflow on the amount of liquid precipitation in September for small catchments, as well as the single period (1991-1996), when the changes of these hydrometeorological characteristics are simultaneously observed, indicate that the phase state of precipitation can be among main factors affecting the increase of low flows of studied rivers.

According the Mann-Kendall and Spearman rank-correlation tests (Kendall, 1975; Mann, 1945) and Pettitt's test (Pettitt, 1979) significant positive trends of simulated streamflow was in May (1.3 mm or $118 \%$ ), September $(10.2 \mathrm{~mm}$ or $38.1 \%)$, in October $(1.3 \mathrm{~mm}$ or $33.3 \%)$ and November $(0.35 \mathrm{~mm}$ or $35.9 \%$ ) (Nesterova et al., 2019). Thus, the simulated trends do coincide with the observed trends of stream flow values (Table 7). The share of liquid precipitation increased by an average of $10 \%$ or $13.6 \mathrm{~mm}$, which corresponds to the observed value of $12 \mathrm{~mm}$. The change point in the autumn season coincides with the observed data and refers to the period 1993-1996 (Fig. 8).

\section{Discussion and conclusion}

The ongoing increase of air temperatures, changes in precipitation and permafrost degradation affect the hydrological cycle via seasonal redistribution of water balance elements, changes in soil wetness and ALT, intensification of ground and surface water runoff exchange (Makarieva, 2019a; Rawlins et al., 2010; Shiklomanov \& Lammers, 2013; Tananaev et al., 2016; Walvoord \& Kurylyk, 2016).

However, the research is complicated by the lack of observed data and the inaccessibility of the study area of the most of the Arctic (Bennett et al., 2015). In the conditions of insufficient information, typical for the high-altitude mountain permafrost regions, the main tool for studying the processes is the method of mathematical modeling. The Arctic places increased demands on hydrological models. The vast majority of hydrological models, well-established in areas with a temperate climate, cannot be used in the permafrost zone. The main requirements are the physical validity of models to natural processes, their versatility in terms of use, both in different landscapes and spatial and temporal scales, and most importantly, the ability to assess the parameters of the model based on the measured properties of landscapes.

Stationary observations in small research catchments are the main source of information on the physical mechanisms of runoff formation and changes of hydrological cycle. But such observations are often expensive to maintain (especially in hard-to-reach regions), require large number of specialists, and are difficult to perform without additional support from the state or other interested stakeholders. In these conditions, the information for improving the models can also be integrated from short-term studies at certain landscapes and watersheds. The concept of such studies was proposed by Vinogradov (1988), he called it "nonstationary research watersheds and plots". The idea was further developed by Vinogradova and Vinogradov (2014) and Gartsman and Shamov (2015) who called this approach "mobile watershed". According to this approach, one or several indicative watersheds or plots are selected in the study area. The research visits are short-term (approximately from 2-3 weeks to 2 months) and last for several years. The observations are vaster and less detailed.

Conducting short-term intensive observations on specially selected representative watersheds, despite their 
fragmentation, allow formulating a general idea of the conditions of runoff formation and hydrological phenomena of the territory in question, and most importantly, approximate quantitative assessment of the parameters of mathematical models of hydrological processes (Vinogradov \& Vinogradova, 2014). However, not having in their basis the tasks of model development and parametrization, or refining existing methods for calculating the flow characteristics, such observations lose most of their value and do not justify the investment.

The three-years extensive observations at the Suntar-Khayata Station can be regarded as the good example of such approach. Among the others expeditions to remote regions we may mention historical studies at the Putorano Plateau in 1988-1990 (Reports..., 1988-1990), recent studies at Chukotka (Tregubov et al., 2020) and the Lena River delta (Tarbeeva et al., 2020). We emphasize the need for open access to the detailed hydrometeorological data of such research sites which can provide the opportunity for multi-criteria assessment of hydrological models in different conditions of permafrost zone (e.g. Fang et al., 2018; Makarieva 2017, 2018a; Rasouli et al., 2019).

In this research, based on the observation data at the high altitude Suntar-Khayata Station (the Indigirka river upper reaches) under the program of the International Geophysical Year in 1957-1959, the parameters of the hydrological model Hydrograph were developed, which describe the runoff formation processes in the high mountain goltsy landscape of the Suntar river basin. Variable states of snow cover and heat dynamics in ground profile in the goltsy zone were simulated, as well as runoff formation process and its changes in recent time throughout the whole catchment of the Suntar river. Modeling results are considered acceptable.

Model calculations have allowed evaluation of long-term average annual values of water balance for different landscapes, their contribution to runoff formation in the mountain river outlet. It is established that the runoff formation occurs mainly in the high-altitude region of goltsy and tundra (about 70\%).

The model reproduced observed trend values and change point of streamflow during the study period supporting the hypothesis that the increase of liquid precipitation in autumn due to climate warming could be the main factor of streamflow changes in the autumn-winter period in this permafrost region.

Currently, in the mountain regions of the Yana, Indigirka and Kolyma rivers basins no hydrological research stations are left to perform a comprehensive study of runoff formation processes. Therefore, development and verification of methods for hydrological processes modeling which may successfully utilize short-term, extremely scarce data, become more of great current interest. The presented study has demonstrated that the Hydrograph model and its further development may become a foundation for solving scientific and practical issues in the research region.

\section{Data Availability Statement}

The data that support the findings of this study are available from the corresponding author upon reasonable request.

\section{Reference}

AIS SMWB: Automated information system for state monitoring of water bodies, URL: https://gmvo.skniivh.ru, reference date: 01.03 .2018 (in Russian)

Ananicheva, M. (2005) Retreat of the glaciers of the northern and southern massifs of the Suntar-Hayat Mountains and the Chersky Range. InMaterials of glaciological research (Eds. Ananicheva M.D. \& Koreisha M.M.), 99, pp. 18-25 (in Russian)

Bennett, J.R., Shaw, J.D., Terauds, A., Smol, J.P., Aerts, R., Bergstrom, D.M. . . Possingham, H.P. (2015) Polar lessons learned: long-term management based on shared threats in Arctic and Antarctic environments. Frontiers in Ecology and the Environment, 13(6), pp. 316-324, doi: 10.1890/140315

Carey, S.K., Woo, M.K. (2000) The role of soil pipes as a slope runoff mechanism, subarctic Yukon, Canada. Journal of Hydrology , 233, pp. 206-222 
Dankers, R., Christensen, O.B. (2005) Climate change impact on snow coverage, evaporation and river discharge in the sub-Arctic Tana Basin, Northern Fennoscandia. Climate Change, 69, pp. 367-392

Dodds, K., Gan, I., Howkins, A. (2010) The IPY-3: The International Geophysical Year (1957-1958). In The History of the International Polar Years (IPYs), doi: 10.1007/978-3-642-12402-0_10.

Fang, X., Pomeroy, J. W., Ellis, C. R., MacDonald, M. K., DeBeer, C. M., Brown, T. (2013) Multivariable evaluation of hydrological model predictions for a headwater basin in the Canadian Rocky Mountains.Hydrology and Earth System Sciences , 17, pp. 1635-1659, https://doi.org/10.5194/hess-17-1635-2013

Fang, X., Luo, S., Lyu, S. (2018). Observed soil temperature trends associated with climate change in the Tibetan Plateau, 1960-2014. Theoretical and Applied Climatology . 10.1007/s00704-017-2337-9.

Garzman, B., Shamov, V. (2015) Field studies of runoff formation in the Far Eastern region based on the modern observation. Water resources management, 42, pp. 589-599. 10.7868/S0321059615060048 (in Russian)

Geocryology of the USSR: Eastern Siberia and the Far East (1989) Eds. Romanovsky, N.N., Gavrilov, A.V., Zaitsev, V.N. et. al. Nedra publishers, Moscow, p.515 (in Russian)

GLIMS and NSIDC (2005, updated 2017): Global Land Ice Measurements from Space glacier database. Compiled and made available by the international GLIMS community and the National Snow and Ice Data Center, Boulder CO, U.S.A. DOI:10.7265/N5V98602

Grave, N.A. (1959) Prior report on heat and moisture regimes of soil and rocks and heat exchange between them, 1958, the site of Suntar-Khayata, Obruchev Permafrost Institute of the Academy of Sciences, NorthWest branch, Yakutsk (in Russian)

Grave, N.A., Gavrilova, M.K., Gravis, G.F., Katasonov, E.M., Kliukin, N.K., Koreisha, G.F., Kornilov, B.A., Chistotinov, L.V. (1964)Freezing of the ground surface and glaciation of the Suntar-Hayat Range (Eastern Yakutia). Science, Moscow, 141 p. (in Russian)

Grave, N.A., Koreisha, M.M. (1957) Interim scientific report on the work of the mountainous Suntar- Khayata glaciological and geocryological Station (program 3 IHY). Obruchev Permafrost Institute of the Academy of Sciences, North-West branch, Yakutsk (in Russian)

Grave, N.A., Koreisha, M.M. (1959) Report on the research of the Suntar-Khayata station, Part II. Obruchev Permafrost Institute of the Academy of Sciences, North-West branch, Yakutsk (in Russian)

Groisman, P. Ya., Bogdanova, E. G., Alexeev, V. A., Cherry, J. E., Bulygina, O. N. (2014) Impact of snowfall measurement deficiencies on quantification of precipitation and its trends over Northern Eurasia, Ice and Snow Journal , 2, pp. 29-43

Hinzman, L., Bettez, N., Bolton, W., Chapin III, F.S., Dyurgerov, M., Fastie, C., .. Yoshikawa, K. (2005) Evidence and implications of recent climate change in Northern Alaska and other Arctic regions. Climatic Change , 72, pp. 251-298. doi:10.1007/s10584-005-5352-2

Hopkinson, C., Young, G.J. (1998) The effect of glacier wastage on the flow of the Bow River at Banff, Alberta, 1951-93. Hydrological Processes, 12, pp. 1745-62

Hudson, C. E., Thompson, J. R. (2019) Hydrological modelling of climate change impacts on river flows in Siberia's Lena River Basin and implications for the Atlantic Meridional Overturning Circulation.Hydrology Research , doi:10.2166/nh.2019.151

Hydrological Yearbook. Volume 8. Issue. 0-7. The basin of the Laptev and East-Siberian seas to the Kolyma river. Yakutsk Department of Hydrometeorology, 1983 (in Russian)

IPCC: Climate Change 2014: Synthesis Report. Contribution of Working Groups I, II and III to the Fifth Assessment Report of the Intergovernmental Panel on Climate Change, IPCC (2014) Geneva, Switzerland, 
151 pp.

Janowicz, J. R., Hedstrom, N., Pomeroy, J. W., Granger, R., Carey S. K. (2004) Wolf Creek Research basin water balance studies. InNorthern Research Basins Water Balance, Eds. Kane, D.L., D. Yang, IAHS Publication, 290, IAHS Press, Wallingford, pp. 195-204

Kendall, M. G. (1975) Rank Correlation Methods, Griffin, London

Koreisha, M.M. (1963) Materials of Glaciological Investigation. Suntar- Khayata. Obruchev Permafrost Institute of the Academy of Sciences, North-West branch, Yakutsk (in Russian)

Krogh, S. A., Pomeroy, J. W. (2018) Impact of future climate and vegetation on the hydrology of an Arctic headwater basin at the Tundra-Taiga transition. Journal of Hydrometeorology, doi:10.1175/jhm-d-18-0187.1

Landscape map of the USSR (1985). Ed. Gudilin I. S. Ministry of Geology of the USSR. Scale 1:2500000 (in Russian)

Lebedeva, L. S., Semenova, O. M., Vinogradova, T. A. (2015) Calculation of the seasonal thawing depth in different landscapes of the Kolyma water-balance station by means of hudrological model "Hydrograph". Part 2. Earth's cryosphere, 19 (2), pp. 35-44

Lebedeva, L. S., Makarieva, O. M., Vinogradova, T. A. (2017) Peculiarities of water balance formation in mountain catchments of Northeastern Russia (a case study for the Kolyma water balance station),Russian Meteorology and hydrology , 4, pp. 90-101

Lytkin, V.M. (2016) Dynamics of glaciers and rock glaciers in the Suntar-Khayata Range in the late Holocene. Ph.D Thesis. Melnikov Permafrost Institute Yakutsk (in Russian)

Makarieva O.M., Lebedeva L.S., Vinogradova T.A. (2020) Modelling of runoff formation processes at small mountain watersheds in the permafrost zone (by the data of the Kolyma Water Balance Station). Cryosphere of the Earth, XXIV, 1, pp. 43-56 DOI: 10.21782/KZ1560-7496-2020-1(43-56)

Makarieva, O., Nesterova, N., Lebedeva, L., Sushansky, S. (2017) Water-balance and hydrology database for a mountainous permafrost watershed in the up-streams of the Kolyma River, Russia - the Kolyma WaterBalance Station, 1948-1997. PANGAEA, https://doi.org/10.1594/PANGAEA.881731

Makarieva, O., Nesterova, N., Lebedeva, L., Sushansky, S. (2018a) Water balance and hydrology research in a mountainous permafrost watershed in upland streams of the Kolyma River, Russia: a database from the Kolyma Water-Balance Station, 1948-1997, Earth System Science Data , 10, pp. 689-710. https://doi.org/10.5194/essd-10-689-2018

Makarieva, O., Nesterova, N., Sherstyukov, A. (2018b) Monthly hydro-climate database for the Yana and Indigirka Rivers basins, Northern Eurasia. PANGAEA, https://doi.org/10.1594/PANGAEA.892775

Makarieva, O., Shikhov, A., Ostashov, A., Nesterova, N. (2018c) Aufeis (naleds) of the North-East of Russia: GIS catalogue for the Indigirka River basin. PANGAEA, https://doi.org/10.1594/PANGAEA.891036

Makarieva, O., Nesterova, N., Post, D. A., Sherstyukov, A., Lebedeva, L. (2019a) Warming temperatures are impacting the hydrometeorological regime of Russian rivers in the zone of continuous permafrost. The Cryosphere, 13(6), pp. 1635-1659. doi: 10.5194/tc-13-1635-2019

Makarieva, O., Shikhov, A., Nesterova, N., Ostashov, A. (2019b) Historical and recent aufeis in the Indigirka River basin (Russia),Earth System Science Data , 11, pp. 409-420. https://doi.org/10.5194/essd-11-409-2019

Makarieva O.M., Nesterova N.V. (2020) Phase State of Precipitation as a Factor of Low Flow in the Yana and Indigirka River Basins. Russian Meteorology and Hydrology , 45 (4), pp. 276-282. DOI: $10.3103 /$ S1068373920040081 
Marsh, C. B., Pomeroy, J. W., Wheater, H. S. (2020). The Canadian Hydrological Model (CHM) v1.0: a multi-scale, multi-extent, variable-complexity hydrological model \&\#8211; design and overview. Geoscientific Model Development , 13(1), 225-247. doi:10.5194/gmd-13-225-2020

Mann, H. B. (1945) Nonparametric tests against trend.Econometrica , 13, pp. 245-259

McCartney, S.E., Carey, S.K., Pomeroy, J.W. (2006) Intra-basin variability of snowmelt water balance computations in a subarctic catchment. Hydrological Processes , 20, pp. 1001-1016. doi:10.1002/hyp.6125

Mikhailov, V. M. (2013) Floodplain taliks of North-East of Russia, Novosibirsk. Geo., 244 p. (in Russian)

Naz, B. S., Frans, C. D., Clarke, G. K. C., Burns, P., Lettenmaier, D. P. (2014) Modeling the effect of glacier recession on streamflow response using a coupled glacio-hydrological model. Hydrology and Earth System Sciences , 18, pp. 787-802. doi:10.5194/hess-18-787-2014

Nijssen, B., O'Donnell, G. M., Hamlet, A. F., Lettenmaier, D. P. (2001) Hydrologic Sensitivity of Global Rivers to Climate Change.Climatic Change , 50(1/2), pp. 143-175. doi:10.1023/a:1010616428763

Nesterova, N., Makarieva, O., Post, D. (2019) Understanding hydrological processes at a remote mountainous continuous permafrost watershed in a changing environment. In 23rd International Congress on Modelling and Simulation, Canberra, ACT, Australia, 1 to 6 December 2019 mssanz.org.au/modsim2019, pp. 11811187

Ohmura, A. (1982) Evaporation from the surface of the Arctic Tundra on Axel Heiberg Island. Water Resources Research , 18(2), pp. 291-300, doi:10.1029/WR018i002p00291

Pettitt, A. N. (1979) A non-parametric approach to the change-point problem. Journal of the Royal Statistical Society: Series C, 28, pp. 126-135

Pohl, S., Marsh, P., Bonsal, B.R. (2006) Modeling the Impact of Climate Change on Runoff and Annual Water Balance of an Arctic Headwater Basin.Arctic, 60, pp. 173-186

Pomeroy, J.W., Essery, R.H., Toth, B. (2004) Implications of spatial distributions of snow mass and melt rate for snow-cover depletion: observations in a subarctic mountain catchment. Annals of Glaciology , 38, pp. 195-201

Rasouli, K., Pomeroy, J. W., Whitfield, P. H. (2019) Are the effects of vegetation and soil changes as important as climate change impacts on hydrological processes? Hydrology and Earth System Sciences , 23(12), pp. 4933-4954. doi:10.5194/hess-23-4933-2019

Rasouli, K., Pomeroy, J. W., Janowicz, J. R., Carey, S. K., Williams, T. J. (2014) Hydrological sensitivity of a northern mountain basin to climate change. Hydrological Processes, 28(14), pp. 4191-4208. doi:10.1002/hyp.10244

Rawlins, M.A., Steele, M., Holland, M.M., Adam, J.C., Cherry, J.E., Francis, J.A., .. Zhang, T. (2010) Analysis of the Arctic System for Freshwater Cycle Intensification: Observations and Expectations. Journal of Climate, 23, pp. 5715-5737, doi:10.1175/2010JCLI3421.1

Reference Book on the Climate of the USSR. Issue 24. Yakut ASSR. Part IV. Humidity, atmospheric precipitation, snow cover (1968) Yakutsk Department for Hydrometeorology, Leningrad, Gidrometeoizdat, 352 p. (in Russian)

Vinogradov, Yu. The results of observations on Kureyka River basin, 1988-1990 (1990) Technical report for expedition, 2, Leningrad (in Russian)

Schramm, I., Boike, J., Bolton, W. R., Hinzman, L. D. (2007) Application of TopoFlow, a spatially distributed 24 hydrological model, to the Imnavait Creek watershed, Alaska. Journal of Geophysical Research , 112, doi:10.1029/2006JG000326 
Semenova, O., Beven, K. (2015) Barriers to progress in distributed hydrological modelling. Hydrological Processes , 29, pp. 2074-2078

Semenova, O., Lebedeva, L., Vinogradov, Y. (2013) Simulation of subsurface heat and water dynamics, and runoff generation in mountainous permafrost conditions, in the Upper Kolyma River basin, Russia.Hydrogeology Journal , 21(1), pp. 107-119. doi:10.1007/s10040-012-0936-1

Semenova, O., Lebedeva, L., Volkova, N., Korenev, I., Forkel, M., Eberle, J., Urban, M. (2015) Detecting immediate wildfire impact on runoff in a poorly-gauged mountainous permafrost basin.Hydrological Sciences Journal , 60. doi:10.1080/02626667.2014.959960

Semenova, O.,Vinogradov, Y., Vinogradova, T., Lebedeva, L. (2014) Simulation of Soil Profile Heat Dynamics and their Integration into Hydrologic Modelling in a Permafrost Zone. Permafrost and Periglacial Processes , 25 (4), pp. 257-269, doi:10.1002/ppp.1820

Shiklomanov, A. I., Lammers, R. B. (2013) Changing Discharge Patterns of High-Latitude Rivers. In Climate Vulnerability: Understanding and Addressing Threats to Essential Resources , 5, pp. 161-175, doi:10.1016/B978-0-12-384703-4.00526-8

Sokolov, B.L. (1975) Aufeises (naleds) and river runoff . Leningrad, Gidrometeoizdat, 190 p. (in Russian)

Spence, C., Kokelj, S. V., Ehsanzadeh E. (2011) Precipitation Trends Contribute to Streamflow Regime Shifts in Northern Canada, Cold Region Hydrology in a Changing Climate, IAHS Publication , 346

State Water Cadastre: Main hydrological characteristics (for 1971-1975 and the whole period of observation until 2007), Volume 17, Leno-Indigirsky district, Leningrad, Gidrometeoizdat (in Russian)

Stuefer, S. L., Arp, C. D., Kane, D. L., Liljedahl, A. K. (2017) Recent extreme runoff observations from coastal arctic watersheds in Alaska.Water Resources Research , 53, pp. 9145-9163. https://doi.org/10.1002/2017WR020567

Tarbeeva, A., Lebedeva, L., Efremov, V., Shamov, V., Makarieva, O. (2020) Water tracks in the lower Lena River basin. E3S Web Conferences, 163 04007, DOI: 10.1051/e3sconf/202016304007

Tananaev, N. I., Makarieva, O. M., Lebedeva, L. S. (2016) Trends in annual and extreme flows in the Lena River basin, Northern Eurasia.Geophysical Research Letters , 43, 20136, doi:10.1002/2016GL070796

Tregubov, O., Gartsman, B., Lebedeva, L., Nuteveket, M., Tarbeeva, A., Uyagansky, K., Shekman, E., Shepelev, V. (2020) Landscape-permafrost conditions and factors of summer runoff formation of small coastal lowland rivers. E3S Web Conferences, 163 05015, DOI: 10.1051/e3sconf/202016305015

USSR surface waters resources. Vol. 1\%. The Far East, Issue 1. The Lena-Indigirka Region (1966) Ed. Muranov A.P., Hydrometeorological pbl. 646 p. (in Russian)

Vasiliev, I.S., Torgovkin, Ya.I. (2002) Spatial distribution of precipitation in Yakutia. Russian Meteorology and Hydrology , 6, pp. 23-32 (in Russian)

Vinogradov, Y.B. (1988) Mathematical Modelling of Runoff Formation: A Critical Analysis . Gidrometeoizdat: Leningrad (in Russian)

Vinogradov, Y. B., Semenova, O. M., Vinogradova, T. A. (2011) An approach to the scaling problem in hydrological modelling: the deterministic modelling hydrological system. Hydrological Processes , 25, pp. 1055-1073. doi: 10.1002/hyp.7901

Vinogradov, Y.B., Vinogradova, T.A. (2014) Applied Hydrology . Saint Petersburg State Forest Technical University, St.Petersburg (in Russian)

Viviroli, D., Archer, D. R., Buytaert, W., Fowler, H. J., Greenwood, G. B., Hamlet, ... Woods, R. (2011) Climate change and mountain water resources: overview and recommendations for research, management and policy, Hydrology and Earth System Sciences , 15, pp. 471-504, https://doi.org/10.5194/hess-15-471-2011 
WMO: Instruments and Observing Methods, Report No. 67. WMO Solid Precipitation Measurement Intercomparison, Final Report (1998) WMO/TD-No. 872, 212 p.

Yang, D., Goodison, B. E. (1995) Accuracy of Tretyakov Precipitation gauge: Results of WMO Intercomparison, Hydrological Processes , 9, p. 877-895

Zhang, L., Jin, X., He, C., Zhang, B., Zhang, X., Li, J., ... DeMarchi, C. (2016) Comparison of SWAT and DLBRM for Hydrological Modeling of a Mountainous Watershed in Arid Northwest China.Journal of Hydrologic Engineering , 21(5), 04016007.doi:10.1061/(asce)he.1943-5584.0001313

Zhang, Y., Carey, S. K., Quinton, W. L. (2008) Evaluation of the algorithms and parameterizations for ground thawing and freezing simulation in permafrost regions. Journal of Geophysical Research, 113(D17). doi:10.1029/2007jd009343

Zhizhin V.I., Zheleznyak M.N., Pulyaev N.A. (2012) Cryogenic processes of the formation of the mountain relief of Suntar-Khayata Range. Vestnik of the M.K. Ammosov North-Eastern Federal University, 9, N 3, pp.73-79 (in Russian)

Zhuravin, S. (2004) Features of water balance for small mountainous basins in East Siberia: Kolyma Water Balance Station case study. IAHS Publ, 290, IAHS, Wallingford, UK, pp. 28-40 
Table 1 Average active layer depth (Grave, 1964)

\begin{tabular}{|c|c|c|c|c|}
\hline Height, m & $\begin{array}{l}\text { Element } \\
\text { topography }\end{array}$ & Composition of active layer & Vegetation cover & $\begin{array}{l}\text { Active layer } \\
\text { depth, } \mathrm{cm}\end{array}$ \\
\hline \multirow{4}{*}{$\begin{array}{l}1700 \text { and } \\
\text { above }\end{array}$} & $\begin{array}{l}\text { flat tops of mountain } \\
\text { ridges }\end{array}$ & $\begin{array}{l}\text { small gravel mudstones with loamy } \\
\text { filler }\end{array}$ & lichen & $60-65$ \\
\hline & \multirow{3}{*}{$\begin{array}{l}\text { deluvial-colluvial } \\
\text { plumes, alluvial cone, } \\
\text { anticline }\end{array}$} & large crushed stone & lichen & $55-60$ \\
\hline & & $\begin{array}{l}\text { crushed stone and granitic subsoil } \\
\text { with loamy aggregate }\end{array}$ & lichen & $60-75$ \\
\hline & & gravelly loam & lichen & $80-85$ \\
\hline \multirow{7}{*}{$500-1700$} & \multirow{2}{*}{$\begin{array}{l}\text { floodplain terraces: } \\
\text { flat surface }\end{array}$} & boulders, pebbles, gravel, sand & larch, lichen & 150 \\
\hline & & dry loam & $\begin{array}{l}\text { larch, Pleurocarpous } \\
\text { moss }\end{array}$ & $80-90$ \\
\hline & low ridge & dry loam & larch, cowberry shrub & $110-115$ \\
\hline & \multirow{4}{*}{ low ridge depressions } & fine sand, waterlogged & sedges & $75-80$ \\
\hline & & loam, waterlogged & sedges & $55-70$ \\
\hline & & loam, waterlogged & Sphagnum moss & $30-45$ \\
\hline & & peaty loam, waterlogged & Sphagnum moss & $25-35$ \\
\hline
\end{tabular}


Table 2 Model parameterization of soil column

\begin{tabular}{|c|c|c|}
\hline Soil parameters & $\begin{array}{l}\text { Goltsy landscape } \\
\text { (gravelly loam) }\end{array}$ & Source of the parameter value \\
\hline Density, $\mathrm{kg} / \mathrm{m}^{3}$ & 2700 & $\begin{array}{l}\text { Grave, 1959; Grave \& Koreisha, 1960; } \\
\text { Grave et al., 1964; Koreisha, } 1963\end{array}$ \\
\hline Porosity, $\mathrm{m}^{3} / \mathrm{m}^{3}$ & 0.42 & $\begin{array}{l}\text { Grave, 1959; Grave \& Koreisha, 1960; } \\
\text { Grave et al., 1964; Koreisha, } 1963\end{array}$ \\
\hline Maximum water holding capacity, $\mathrm{m}^{3} / \mathrm{m}^{3}$ & 0.12 & $\begin{array}{l}\text { Grave, 1959; Grave \& Koreisha, 1960; } \\
\text { Grave et al., 1964; Koreisha, } 1963\end{array}$ \\
\hline Maximum ice holding capacity, $\mathrm{m}^{3} / \mathrm{m}^{3}$ & 0.26 & Grave (1959) \\
\hline Infiltration coefficient, $\mathrm{mm} / \mathrm{min}$ & $10-0.1$ & Semenova et al. (2013) \\
\hline Specific heat capacity, $\mathrm{J} /\left(\mathrm{kg}^{\circ} \mathrm{C}\right)$ & 840 & Typical properties of soil material \\
\hline Specific heat conductivity, $\mathrm{W} /\left(\mathrm{m}^{\circ} \mathrm{C}\right)$ & 1.5 & Typical properties of soil material \\
\hline Hydraulic parameters of the flow elements & $0.005-10$ & Manual calibration \\
\hline
\end{tabular}


Table 3 Meteorological information

\begin{tabular}{|c|c|c|c|c|c|c|c|c|}
\hline Index & $\begin{array}{c}\text { Meteorological } \\
\text { station }\end{array}$ & $\begin{array}{c}\text { Lat, } \\
\text { degree }\end{array}$ & $\begin{array}{c}\text { Long, } \\
\text { degree }\end{array}$ & $\begin{array}{c}\text { Period of } \\
\text { record }\end{array}$ & $\begin{array}{c}\text { Altitude, } \\
\mathrm{m}\end{array}$ & $\begin{array}{c}\text { Mean } \\
\text { temperature, } \\
\text { C }\end{array}$ & $\begin{array}{c}\text { Annual } \\
\text { precipitation, } \\
\mathrm{mm}\end{array}$ & $\begin{array}{c}\text { Mean annual air } \\
\text { moisture deficit, } \\
\mathrm{mb}\end{array}$ \\
\hline 24784 & $\begin{array}{c}\text { Suntar- } \\
\text { Khayata }\end{array}$ & 62.63 & 140.80 & $1957-1964$ & 2068 & -13.8 & 688 & 1.1 \\
\hline 24781 & $\begin{array}{c}\text { Nizhnyaya } \\
\text { Baza }\end{array}$ & 63.05 & 140.97 & $1957-1964$ & 1350 & -14.1 & 307 & 1.8 \\
\hline 24679 & Vostochnaya & 63.22 & 139.60 & $\begin{array}{c}1957- \\
2012^{*}\end{array}$ & 1287 & -13.7 & 292 & 1.8 \\
\hline 24684 & Agayakan & 63.33 & 141.73 & $\begin{array}{c}1957- \\
2012^{*}\end{array}$ & 776 & -15.8 & 224 & 2.2 \\
\hline
\end{tabular}


Table 4 Ground temperature at the different depths in $\mathbf{1 9 5 8}$

\begin{tabular}{|c|c|c|c|c|}
\hline \multirow{2}{*}{ Depth } & \multirow{2}{*}{$\begin{array}{c}\text { Observed mean } \\
\text { monthly } \\
\text { temperature, }\end{array}$} & $\begin{array}{c}\text { Mean absolute } \\
\text { deviations between } \\
\text { simulated and observed } \\
\text { value, }{ }^{\circ} \mathrm{C}\end{array}$ & \multicolumn{2}{|c|}{$\begin{array}{c}\text { Maximum deviation between simulated } \\
\text { and observed value, month }\end{array}$} \\
\cline { 4 - 5 } & & 1.1 & $\begin{array}{c}\text { Maximum deviation, } \\
{ }^{\circ} \mathrm{C}\end{array}$ & Month \\
\hline $5 \mathrm{~cm}$ & -22.1 & 0.7 & $+3,6$ & December \\
\hline $50 \mathrm{~cm}$ & -17.2 & 0.2 & $+4,0$ & November \\
\hline $100 \mathrm{~cm}$ & -9.6 & 0.3 & $-1,7$ & June \\
\hline $200 \mathrm{~cm}$ & -10.7 & & & January \\
\hline
\end{tabular}


Table 5 The results of streamflow modelling, the Suntar River

\begin{tabular}{|c|c|c|c|c|c|c|c|}
\hline Period & Yo & Ys & P & E & Qo & Qs & NS (av, med, max/min) \\
\hline $1957-1964$ & 180 & 199 & 344 & 143 & 1659 & 1200 & $0.75,0.75,0.88 / 0.40$ \\
\hline $1966-2012$ & 180 & 203 & 332 & 127 & 1910 & 1905 & $0.58,0.67,0.87 /-0.90$ \\
\hline
\end{tabular}

where $\mathrm{Yo}$ and $\mathrm{Ys}$ - observed and simulated average annual runoff, mm; P - precipitation, mm; E - evaporation, $\mathrm{mm}$; Qo and Qs - maximum observed and simulated flow, $\mathrm{m} 3$ / s; NS av is the average NS; max and min - the maximum and minimum value of NS. 
Table 6 Simulated water balance of RFC at the Suntar River, 1957-1964

\begin{tabular}{|c|c|c|c|c|}
\hline & General & RFC \#1 & RFC \#2 & RFC \#3-4 \\
\hline Altitude, $\mathrm{m}$ & $828-2794$ & $1900-2700$ & $1450-1900$ & $1100-1450$ \\
\hline Share of catchment area, $\%$ & 100 & 9.4 & 31.3 & 59.4 \\
\hline Precipitation, $\mathrm{mm}$ & 344 & 618 & 356 & 292 \\
\hline Streamflow, mm & 199 & 567 & 263 & 105 \\
\hline Evaporation, $\mathrm{mm}$ & 143 & 54 & 86 & 186 \\
\hline Flow percentage, $\%$ & 100 & 20 & 49 & 31 \\
\hline Coefficient of flow, $\mathrm{m} 3 / \mathrm{m} 3$ & 0.59 & 0.91 & 0.75 & 0.36 \\
\hline
\end{tabular}


Table 7 Observed and simulated flow trends, mm (\%)

\begin{tabular}{|c|c|c|c|c|}
\hline Flow trend/ Month & May & September & October & November \\
\hline Observed & $6.8(103)$ & $9.9(49)$ & $3.3(70)$ & $0.43(52)$ \\
\hline Simulated & $11.3(118)$ & $10.2(38.1)$ & $1.3(33.3)$ & $0.35(35.9)$ \\
\hline
\end{tabular}




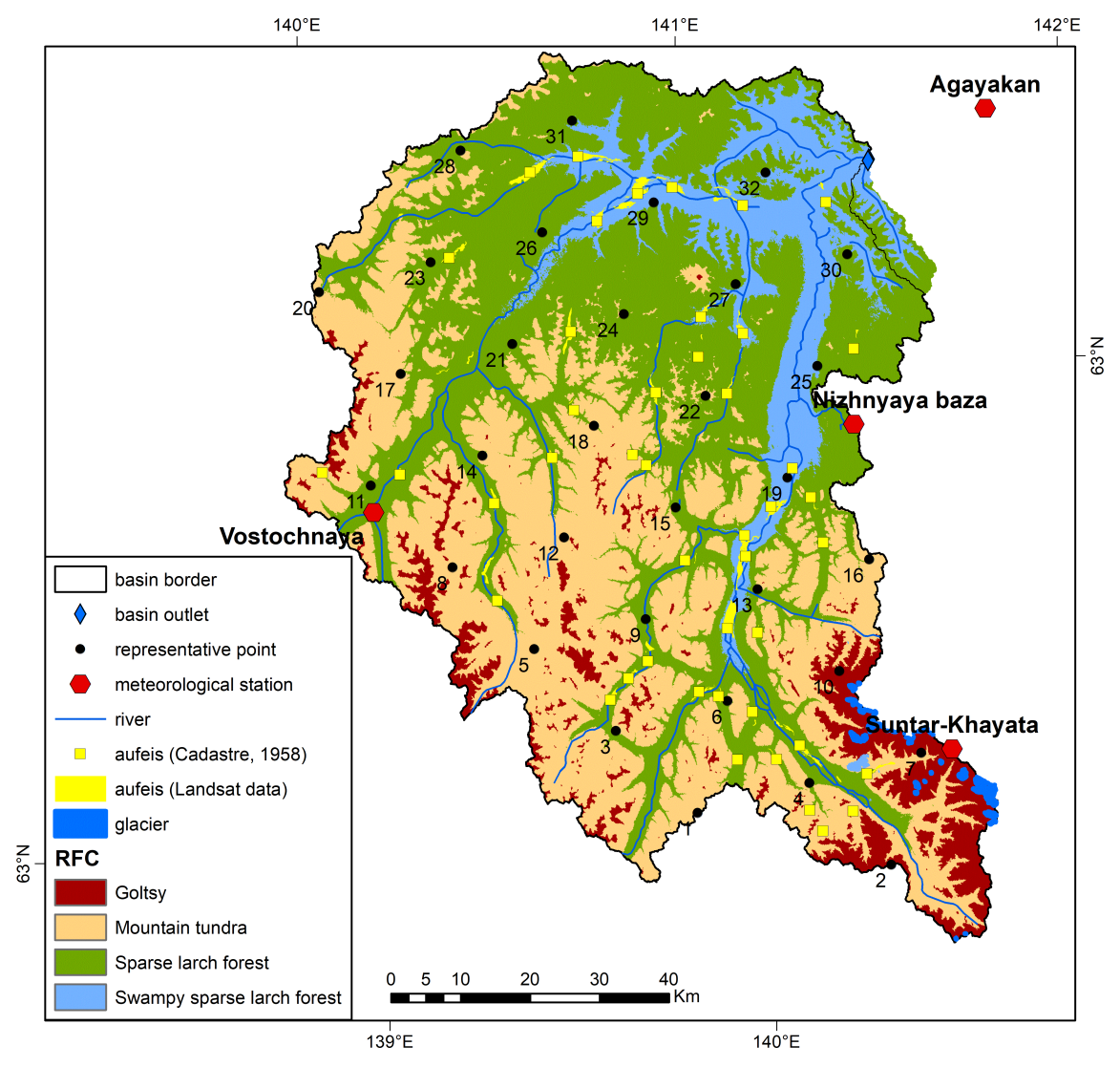

A
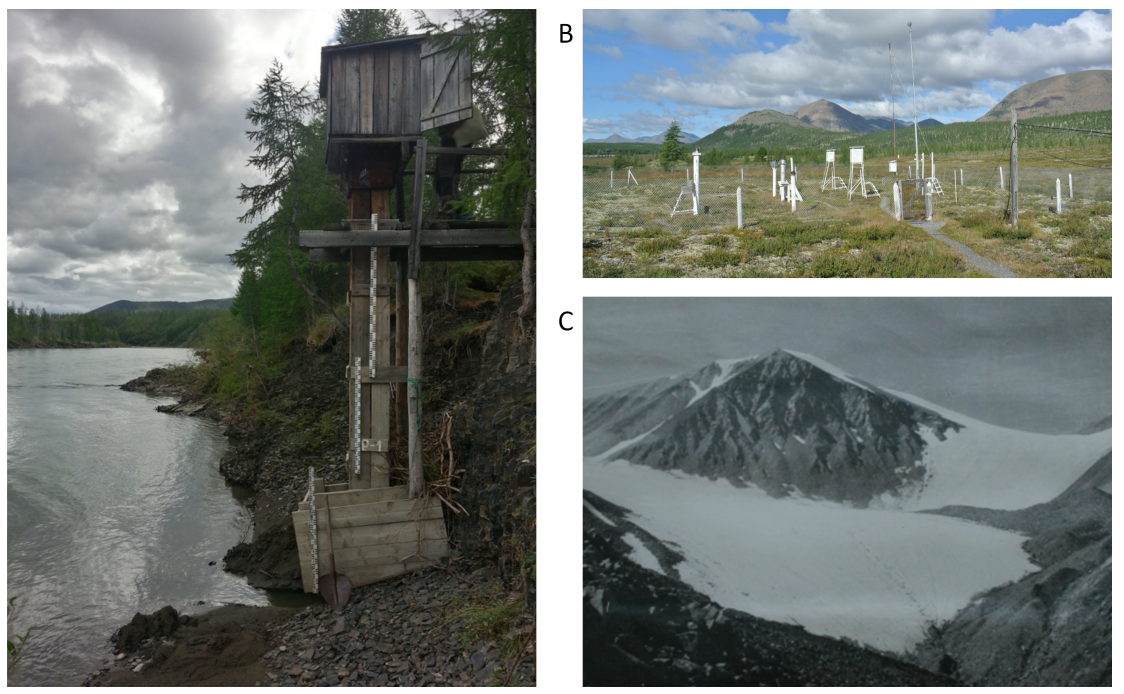

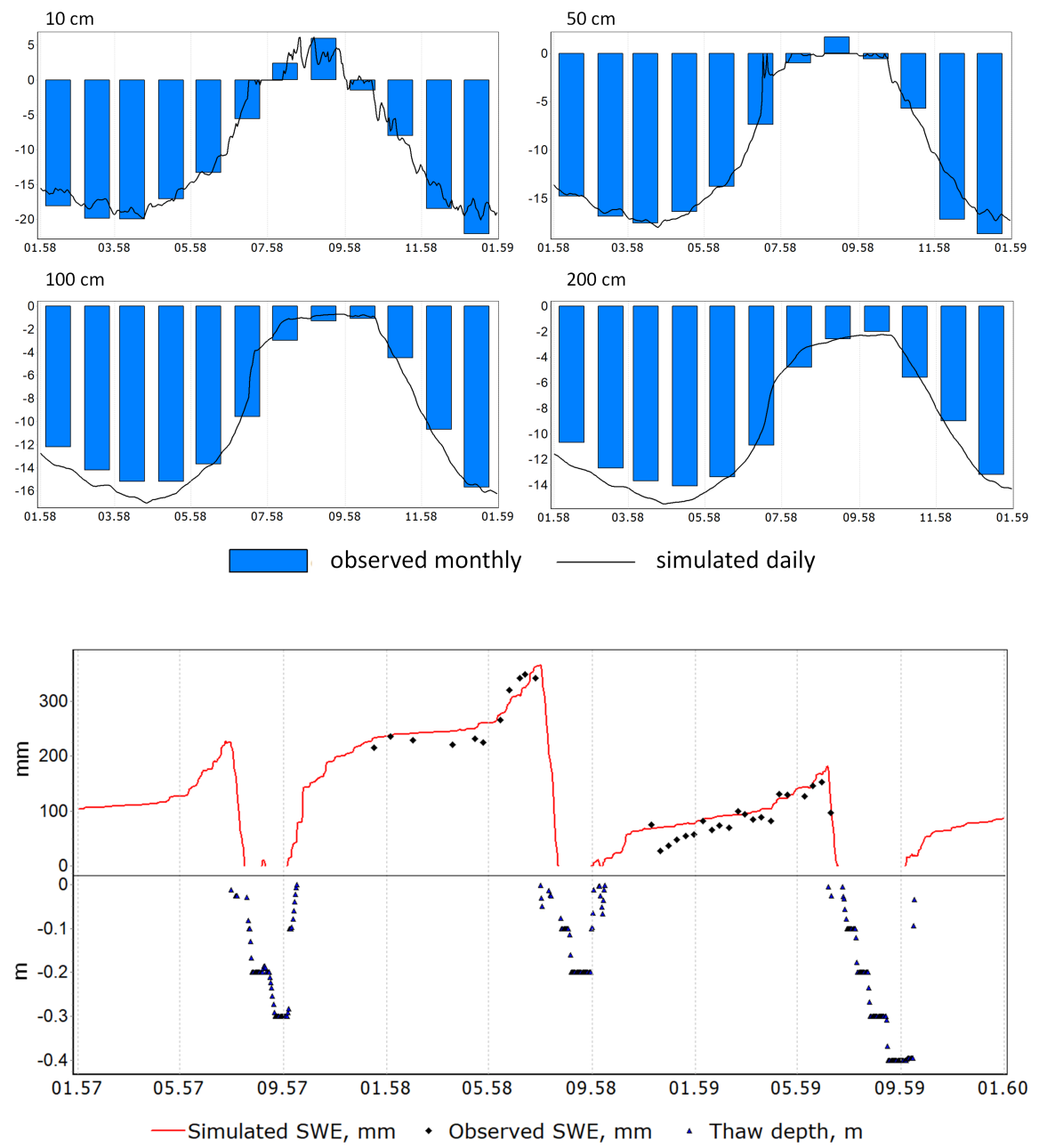

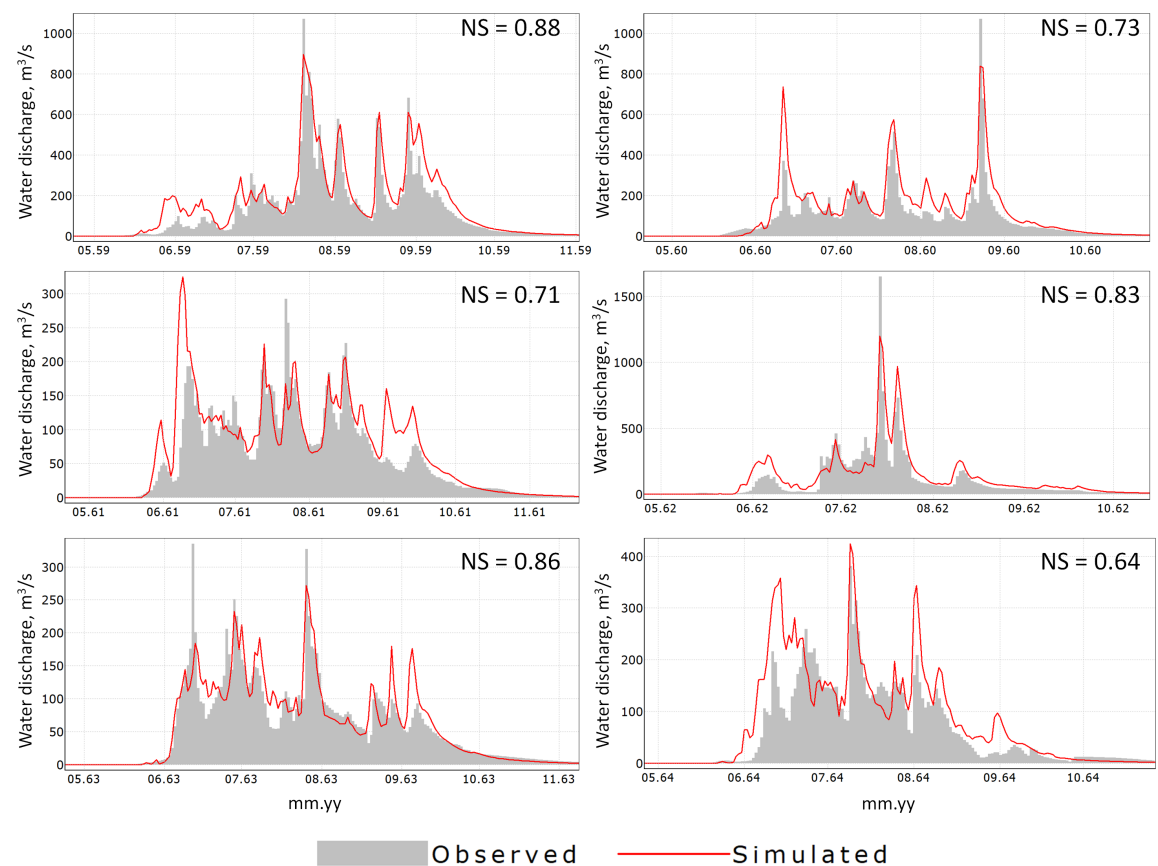

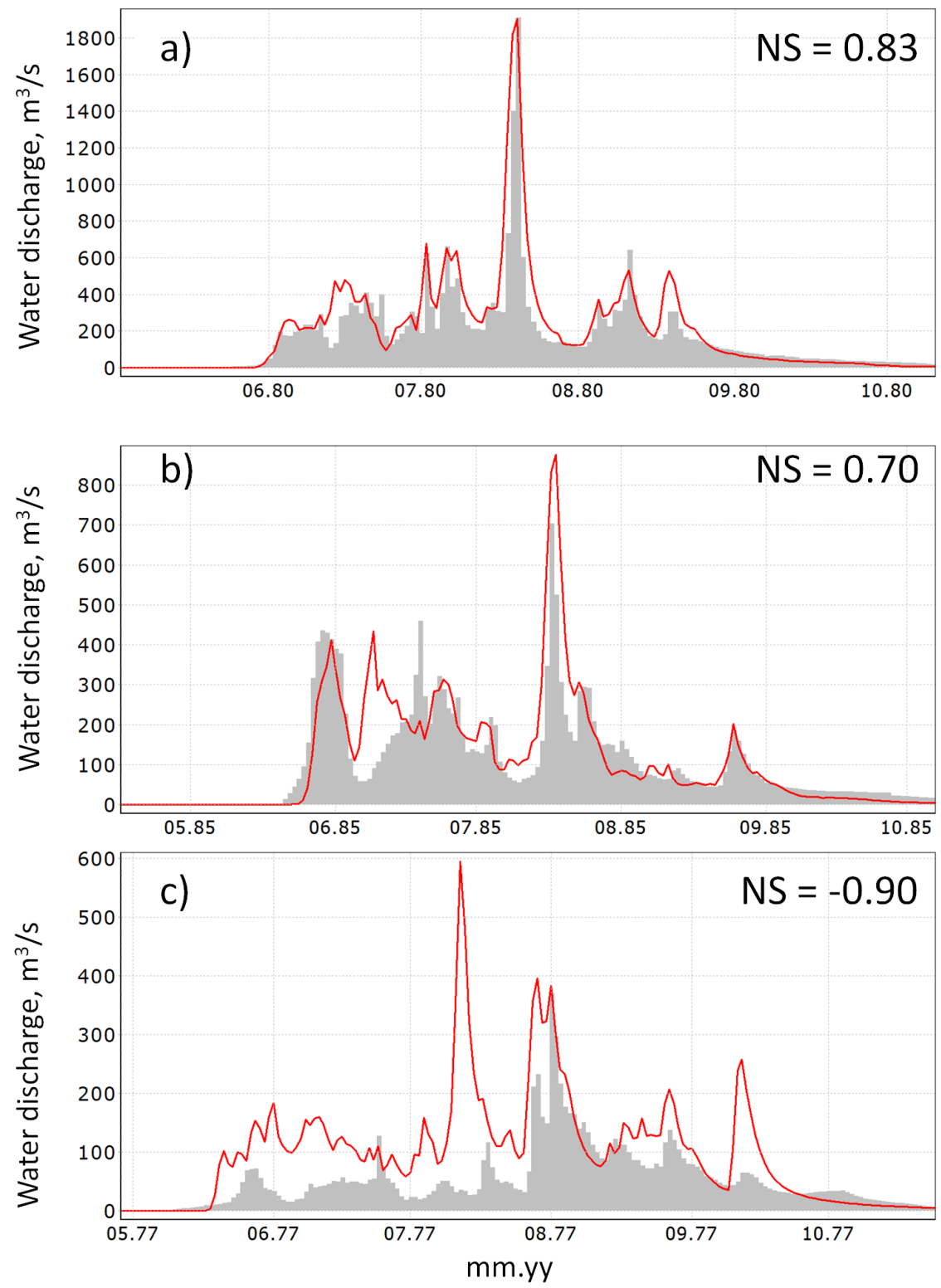

Observed Simulated 


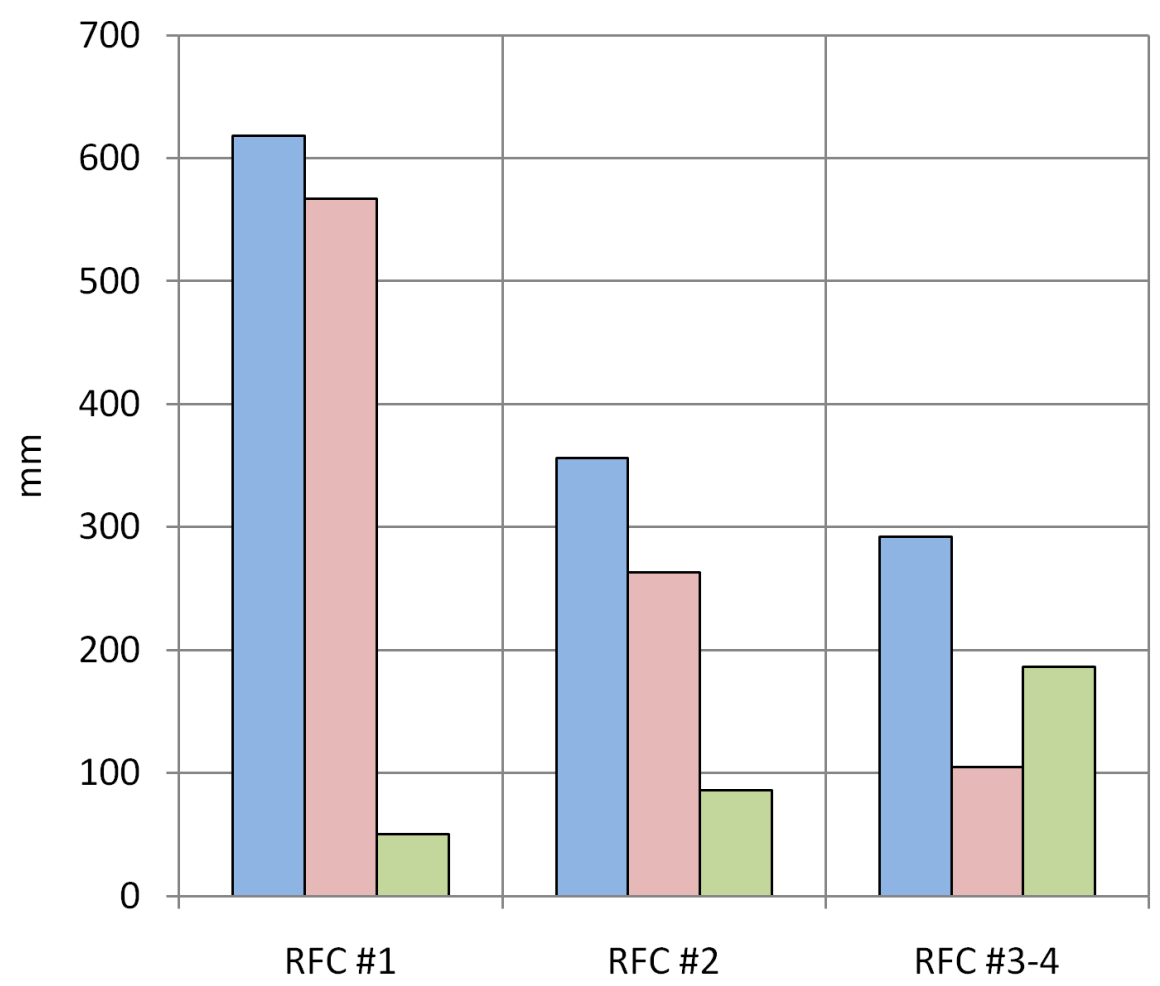

$\square$ Precipitation, $\mathrm{mm} \quad \square$ Flow, $\mathrm{mm} \quad \square$ Evaporation, $\mathrm{mm}$
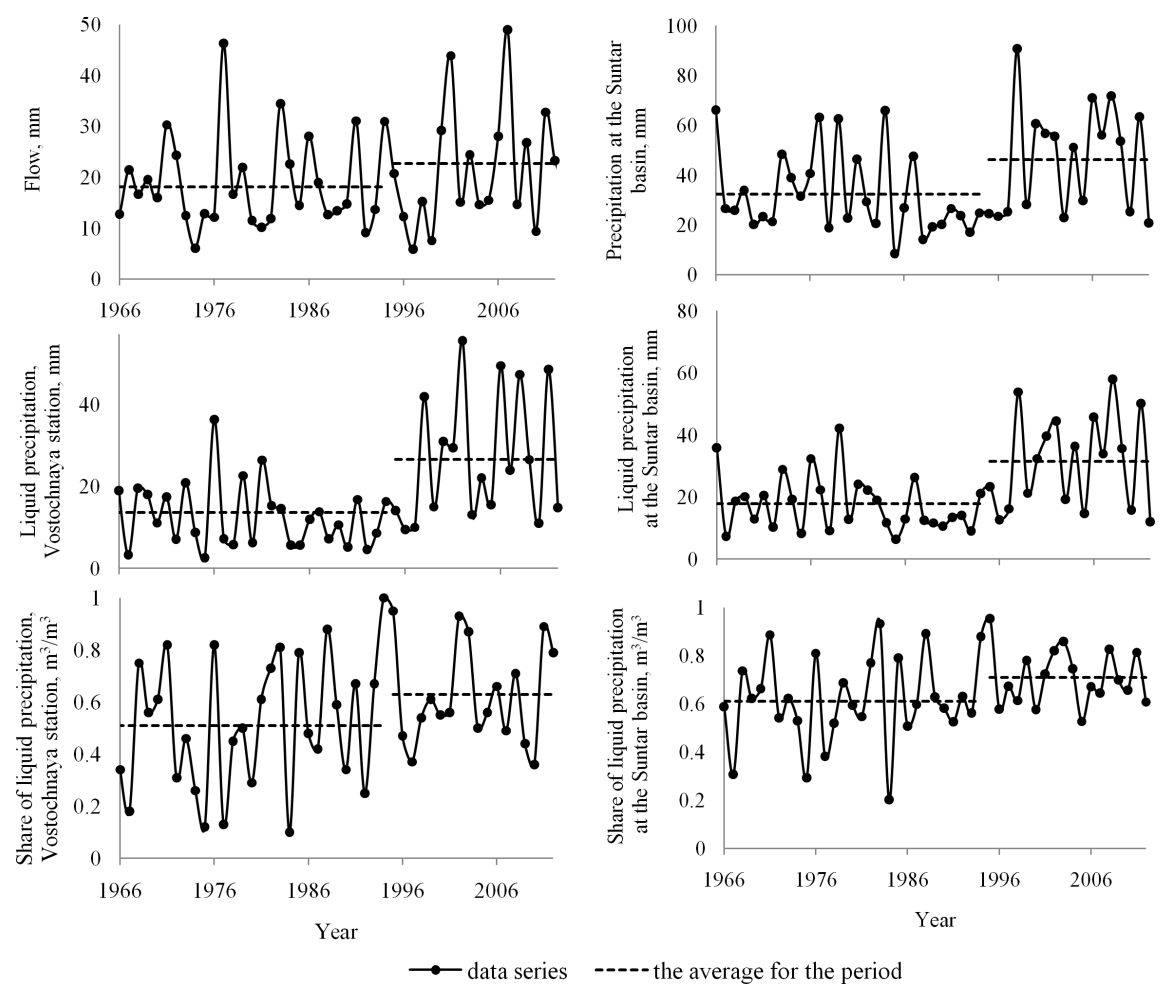